\title{
KARAKTERISTIK DAN SENYAWA BIOAKTIF EKSTRAK KERING DAUN KLUWIH DARI POSISI DAUN YANG BERBEDA
}

\author{
Deivy Andhika Permata dan Alfi Asben \\ Program Studi Teknologi Hasil Pertanian, Fakultas Teknologi Pertanian, Universitas Andalas \\ Email: deivyandhika@yahoo.co.id
}

\begin{abstract}
ABSTRAK
Indonesia kaya akan keanekaragaman hayati, diantaranya tanaman kluwih. Di masyarkat luas rebusan daun kluwih dikenal sebagai obat diabetes. Penelitian ini merupakan penelitian deskriptif, sebagai langkah awal melihat potensi ektrak kering daun kluwih sebagai sediaan yang dapat diaplikasikan dalam pembuatan pangan fungsional, obat-obatan atau sediaan jamu. Daun kluwih pada posisi berbeda dilakukan ekstraksi dengan pelarut air kemudian dipekatkan menggunakan rotary vacuum evaporator kemudian dibuat menjadi ekstrak kering dengan bantuan freeze dryer. Pengamatan yang dilakukan, yaitu rendemen, kadar air, kadar abu, analisis kualitatif fitokimia, serta total polifenol. Berdasarkan hasil penelitian diperoleh karakteristik dan komponen bioaktif ekstrak kering daun muda, tua dan sangat tua berturut-turut sebagai berikut: rendemen sebesar 5,49\%, 5,23\% dan 5,34\%; kadar air sebesar $10,11 \%, 10,16 \%$, dan 10,30\%; kadar abu 12,76\%, 12,35\%, dan 12,30\%. Pada semua ekstrak daun mengandung alkaloid, triterpenoid, flavonoid, saponin, fenolik dan tanin. Total polifenol ekstrak kering daun muda, tua dan sangat tua berturut-turut, yaitu 11.175 mgGAE/g, 10.238,89 mgGAE/g, dan $7.858,33 \mathrm{mgGAE} / \mathrm{g}$.

Kata kunci- kluwih; polifenol; fitokimia
\end{abstract}

\section{PENDAHULUAN}

Indonesia kaya akan keanekaragaman hayati, diantaranya tanaman kluwih. Tanaman kluwih (Arthocarpus camansi)dapat tumbuh baik di dataran rendah khatulistiwa di bawah 600-650 m dengan daun alternatif, besar, dan panjang 40-60 cm (Ragone, 2006). Menurut Mariane et al. (2011) ekstrak etanol kluwih mengandung alkaloid, flavonoid, dan tanin, serta mampu menurunkan kadar glukosa darah. Nasution, Barus, Nasution, dan Saidi (2014) juga mengemukakan bahwa ekstrak n-heksan, etil asetat, dan metanol daun kluwih memiliki aktivitas antidiabetik.

Di masyarakat luas pemanfaatan tanaman herbal biasanya dilakukan dengan merebusnya dengan air, demikian juga dengan kluwih. Namun sejauh ini belum ditemukan penelitian yang mengkaji komponen bioaktif ekstrak air daun kluwih. Disamping itu posisi daun juga menentukan kandungan senyawa bioaktif yang terdapat di dalamnya. Berdasarkan beberapa penelitian mengemukanan bahwa umur daun mempengaruhi total polifenol dan aktifitas antioksidan dari kopi kawa (Khotimah, 2014), teh daun tanaman kakao (Supriyanto et al., 2014), serta ekstrak daun beluntas (Widyawati et al., 2011).

Berdasarkan uraian diatas perlu dilakukan penelitian tentang karakteristik dan komponen bioaktif yang terkandung dalam ekstrak kering daun kluwih dengan pelarut air berdasarkan posisi daun yang berbeda. Nantinya diharapkan ekstrak yang diperoleh dapat diaplikasikan dalam pembuatan pangan fungsional, obat-obatan atau sediaan jamu.

\section{METODOLOGI PENELITIAN}

\section{A. Metode Penelitian}

Penelitian ini merupakan penelitian deskriptif, sebagai langkah awal melihat potensi ektrak kering daun kluwih sebagai sediaan yang dapat diaplikasikan dalam pembuatan pangan fungsional, obat-obatan atau sediaan jamu. Daun kluwih pada posisi berbeda dilakukan ekstraksi dengan pelarut air kemudian dipekatkan menggunakan rotary vacuum evaporator dan dikeringkan dengan bantuan freeze dryer. Pengamatan yang dilakukan pada ektrak kering daun kluwih adalah rendemen, analisa kadar air, analisa kadar abu, analisa fitokimia dan analisa total polifenol, yang masing-masing dilakukan sebanyak 3 kali ulangan. 


\section{B. Bahan dan Alat}

Bahan yang digunakan adalah daun kluwih pada posisi daun muda, daun tua, dan daun sangat tua, akuades, $\mathrm{HCl}$, dragendorf, $\mathrm{CHCl}_{3}$, asam asetat anhidrat, $\mathrm{H}_{2} \mathrm{SO}_{4}$ pekat, etanol, magnesium, $\mathrm{FeCl}_{3}$, metanol, $\mathrm{Na}_{2} \mathrm{CO}_{3}$, asam galatdan lain-lain. Peralatan yang digunakan meliputi oven, desikator, tanur, timbangan analitik, spektofotometer, rotary vacuum evaporator, freeze dyer, serta alat-alat gelas.

\section{Pelaksanaan Penelitian}

Ekstraksi daun kluwih berdasarkan posisi daun sebanyak $200 \mathrm{~g}$ daun kluwih ditambahkan dengan akuades $1 \mathrm{l}$, lalu direbus sehingga volume air menjadi $100 \mathrm{ml}$, larutan disaring dan ampasnya dibilas menggunakan akuades beberapa kali (menggunakan $400 \mathrm{ml}$ akuades), filtrat dikumpulkan dan dipekatkan dengan rotary vacuum evaporator, sehingga volumenya $100 \mathrm{ml}$. Lalu dikeringkan dengan menggunakan freeze dyer. Pengamatan yang dilakukan pada ektrak kering daun kluwih adalah rendemen, analisa kadar air, analisa kadar abu, analisa fitokimia dan analisa total polifenol.

\section{Pengamatan}

a. Penetapan Kadar Air (Yenrina, 2015)

1. Cawan kosong dan tutupnya dikeringkan dalam oven selama 20 menit kemudian didinginkan dalam desikator selama 10 menit kemudian ditimbang (Wogram)

2. Sebanyak 5 gram sampel ditimbang dalam cawan tersebut, sampel disebarkan merata (W1 gram)

3. Cawan beserta isi dan tutupnya ditempatkan di dalam oven selama 6 jam.

4. Cawan beserta isi diangkat dan didinginkan dalam desikator kemudian timbang (W2 gram)

5. Dikeringkan kembali dalam oven dan timbang sampai diperoleh bobot tetap.

Perhitungan:

Kadar air $(\%)=\underline{\mathrm{W} 1-(\mathrm{W} 2-\mathrm{Wo})} \times 100 \%$

(W1)

\section{b. Penetapan Kadar Abu (Yenrina, 2015)}

1. Disiapkan cawan pengabuan, kemudian keringkan dalam tanur selama 15 menit, dinginkan dalam desikator, dan timbang (Wo gram).

2. Sebanyak 3 - 5 gram sampel ditimbang dan ditambahkan dalam cawan tersebut (W1 gram).

3. Lalu dibakar di atas Hot plate sampai tidak berasap.

4. Kemudian diletakkan dalam tanur pengabuan, dibakar sampai didapat abu berwarna abu-abu atau sampai beratnya tetap. Pengabuan dilakukan dalam dua tahap : pertama pada suhu sekitar $400^{\circ} \mathrm{C}$ dan kedua pada suhu $550^{\circ} \mathrm{C}$.

5. Cawan dan sampel didinginkan dalam desikator, kemudian ditimbang (W2 gram).

Perhitungan

Kadar abu $(\%)=\underline{(\mathrm{W} 2-\mathrm{Wo})} \times 100 \%$

$$
\text { (W1-Wo) }
$$

\section{c. Analisa Fitokimia(Harborne,1987)}

1. Uji Kualitatif Alkaloid

Sebanyak setengah gram ekstrak kering daun kluwih ditambah $0,5 \mathrm{ml} \mathrm{HCl} 1 \%$, kemudian ditambahkan 1-2 tetes dragendorf. Hasil uji positif ditunjukan apabila hasil pengujian menghasilkan warna jingga.

2. Uji Steroit atau Triterpenoid

Sebanyak setengah gram ekstrak kering daun kluwih ditambah $0,5 \mathrm{ml} \mathrm{CHCl}_{3}$ dan $0,5 \mathrm{ml}$ asam asetat anhidrat dimasukan ke dalam tabung reaksi. Ke dalam tabung tersebut ditetesi dengan 1$2 \mathrm{ml} \mathrm{H}_{2} \mathrm{SO}_{4}$ pekat melalui dinding tabung. Apabila terbentuk warna unggu-merah, maka ekstrak positif mengandung triterpenoid. Sedangkan apabila terbentuk warna hijau atau biru maka ekstrak positif mengandung steroid. 
3. Uji Kualitatif Flavonoid

Sebanyak $200 \mathrm{mg}$ ekstrak kering daun kluwih ditambahkan dengan $5 \mathrm{ml}$ etanol dan dipanaskan selama 5 menit didalam tabung reaksi. Selanjutnya beberapa tetes $\mathrm{HCl}$ pekatditambah. Kemudian ditambahkan 0,2 gr magnesium. Timbulnya warna merah tua (magenta) dalam waktu 3 menit menunjukan adanya flavonoid.

4. Uji Kualitatif Saponin

Sebanyak 0,5 gram ekstrak kering daun kluwih dimasukkan kedalam tabung reaksi. Kemudian ditambahkan air panas, didinginkan lalu dikocok kuat selama 10 detik. Jika terbentuk buih yang mantap setinggi 1 sampai $10 \mathrm{~cm}$, tidak dikurangi dari 10 menit dan tidak hilang dengan penambahan $\mathrm{HCl} 2 \mathrm{~N}$ menunjukkan adanya saponin.

5. Uji Kualitatif Fenolik

Sebanyak 1 gram ekstrak kering daun kluwih ditambahkan dengan $20 \mathrm{ml}$ etanol $70 \%$. Larutan yang terbentuk diambil sebanyak $1 \mathrm{ml}$ kemudian ditambahkan 2 tetes larutan $\mathrm{FeCl}_{3} 5 \%$. Hasil positif adanya senyawa fenol dalam bahan. Ditunjukan dengan terbentuknya warna hijau atau hijau biru.

6. Uji Kualitatif Tanin

Setengah gram ekstrak kering daun kluwih dimasukkan dalam tabung reaksi kemudian ditambahkan 1-2 ml akuades dan 2 tetes larutan $\mathrm{Fe}_{3} \mathrm{Cl}_{3} 1 \%$. Apabila larutan menghasilkan warna hijau kebiruan, maka ekstrak mengandung tanin.

\section{d. Total Polifenol}

Pada penentuan total polifenol digunakan asam galat sebagai standar acuan dan hasilnya dinyatakan dalam persen ekivalen asam galat/galat acid equivalent (EAG/GAE). Untuk pengukuran terlebih dahulu dibuat kurva standar asam galat, dengan melarutkan asam galat pada berbagai konsentrasi. Dari kurva tersebut diperoleh persamaan garis linear yang akan digunakan untuk menentukan kadar total polifenol. Ektrak kering daun kluwih dilarutkan dalam metanol, kemudian diambil sebanyak $0,05 \mathrm{ml}$ dan dimasukan ke dalam tabung reaksi, lalu ditambahkan 2,5 pereaksi folin ciocalteu 10\%, $2 \mathrm{ml} \mathrm{Na}$ Karbonat (7,5\% b/v). Larutan diinkubasi pada suhu $37^{\circ} \mathrm{C}$ selama 30 menit. Kemudian serapan diukur pada panjang gelombang $750 \mathrm{~nm}$. Hasil serapan dihitung dengan memakai persamaan garis linear dari kurva standar asam galat (Shukor, 2013).

\section{HASIL DAN PEMBAHASAN}

\section{A. Karakteristik Fisik Daun Kluwih}

Bedasarkan hasil pengamatan yang dilakukan diperoleh karakteristik fisik daun kluwih seperti pada Tabel 1 berikut ini.

Tabel 1. Karakteristik Fisik Daun Kluwih

\begin{tabular}{lcccccc}
\hline \multirow{2}{*}{ Posisi daun } & $\begin{array}{c}\text { Berat daun } \\
\text { utuh }(\mathbf{g})\end{array}$ & Warna & Tekstur & \multicolumn{2}{c}{ Ukuran (cm) } & Jumlah \\
\cline { 5 - 6 } & & & & Panjang & Lebar & ruas jari \\
\hline Muda & $158,0 \pm 0,7$ & Hijau muda & Lunak & $77,0 \pm 0,8$ & $55,5 \pm 0,6$ & $9,0 \pm 0,8$ \\
Tua & $135,4 \pm 0,4$ & Hijau & Keras & $85,0 \pm 0,5$ & $66,0 \pm 0,4$ & $9,0 \pm 0,6$ \\
Sangat Tua & $140,8 \pm 0,8$ & Hijau tua & Sangat keras & $89,5 \pm 0,7$ & $69,5 \pm 0,6$ & $11,0 \pm 0,7$ \\
\hline
\end{tabular}

Daun muda kluwih yang digunakan pada penelitian ini merupakan daun ke1-2 dari pucuk daun. Daun muda memiliki warna hijau muda dengan tekstur yang lunak. Daun tua kluwih yang digunakan adalah daun ke 3-4 dari pucuk daun dengan warna hujai dan tektur keras, sedangkan daun sangat tua merupakan daun ke 5-6 dari pucuk daun dengan warna hijau tua bertekstur sangat keras jika dibandingkan dengan daun muda dan daun tua. Penampakan daun kluwih pada posisi yang berbeda dapat dilihat pada Gambar 1 berikut ini: 


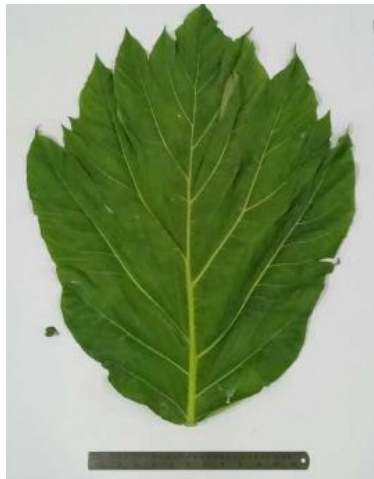

A

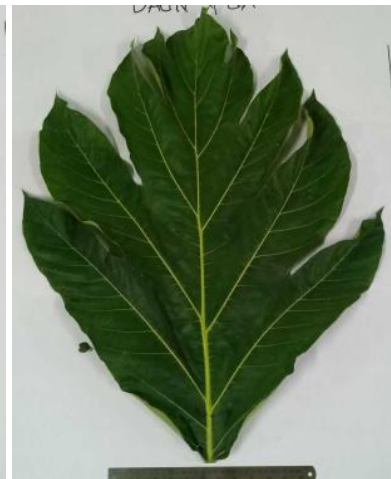

B

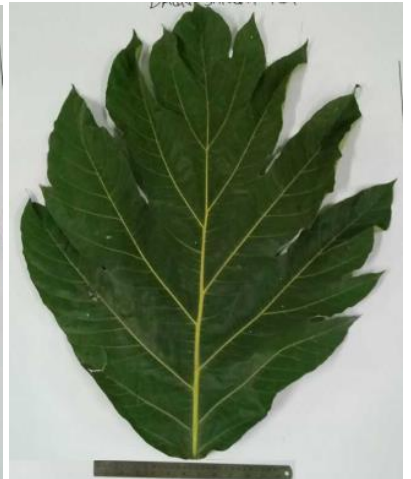

$\mathrm{C}$

Gambar 1. Daun Muda (A), Daun Tua (B), Daun Sangat Tua (C)

\section{B. Karakteristik Fisik dan Kimia Ekstrak Kering Kluwih}

Ekstrak kering daun kluwih diperoleh dengan cara merubus daun kluwih dengan air kemudian dipekatkan dengan rotary vacuum evaporator, hasil pekatan tersebut dikeringkan dengan bantuan freeze dyer. Gambar 2 memperlihatkan ekstrak kering daun kluwih pada posisi daun yang berbeda.

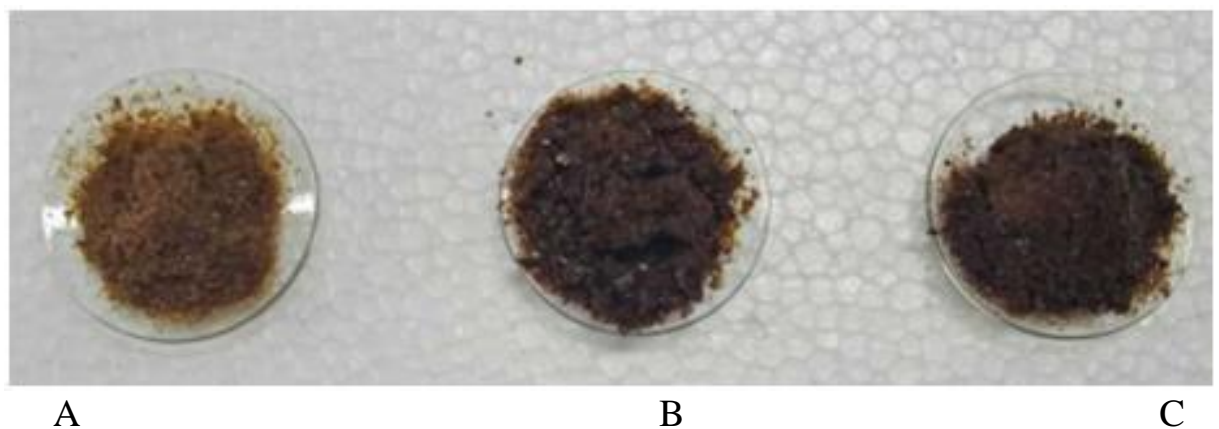

Gambar 2. Ektrak Kering Daun Kluwih Pada Posisi Daun yang Berbeda, Ektrak Kering dari Daun Muda (A), Ektrak Kering dari Daun Tua (B), Ektrak Kering dari Daun Sangat Tua (C)

Hasil analisis fisik dan kimia ekstrak daun kluwih pada posisi daun yang berbeda dapat dilihat pada Tabel 2 berikut ini:

Tabel 2. Karakteristik Fisik dan Kimia Ekstrak Kering Kluwih Pada Posisi Daun yang Berbeda

\begin{tabular}{cccc}
\hline Posisi Daun & Rendemen (\%) & Kadar Air (\%) & Kadar Abu (\%) \\
\hline Muda & $5,49 \pm 0,37$ & $10,11 \pm 0,17$ & $12,76 \pm 1,05$ \\
Tua & $5,23 \pm 0,23$ & $10,16 \pm 0,06$ & $12,35 \pm 0,14$ \\
Sangat Tua & $5,34 \pm 0,19$ & $10,30 \pm 0,31$ & $12,30 \pm 0,31$ \\
\hline
\end{tabular}

Dari Tabel 2, diketahui bahwa rendemen yang dihasilkan pada masing-masing posisi daun \pm $5 \%$ dengan kadar air $\pm 10 \%$ dan kadar abu $\pm 12 \%$. Penetapan kadar air pada ekstrak kering daun kluwih merupakan cara untuk mengukur banyaknya air yang terdapat di dalam bahan tersebut. Metode pengeringan yang digunakan adalah metode oven, metode ini berprinsip pada pengukuran kehilangan berat akibat menguapnya air dari bahan yang dikeringkan pada suhu sekitar lebih dari $100^{\circ} \mathrm{C}$.

Abu merupakan residu anorganik yang didapat dengan pengabuan atau memanaskan pada suhu tinggi $>450^{\circ} \mathrm{C}$ dan atau pendestruksian komponen-komponen organik dengan asam kuat. Residu anorganik ini terdiri dari bermacam-macam mineral yang komposisi dan jumlahnya tergantung pada jenis bahan dan metode analisis yang digunakan. Abu dalam bahan ditetapkan dengan menimbang sisa mineral sebagai hasil pembakaran bahan organik pada suhu sekitar $550^{\circ} \mathrm{C}$ (Yenrina, 2015). Mineral yang terkandung dalam daun kluwih yaitu kalsium dan besi. 
Berdasarkan hasil penelitian diperoleh bahwa semua ekstrak kering daun kluwih mengandung alkaloid, steroid atau terpenoid, flavonoid, saponin, fenolik dan tanin (Tabel 3).

Tabel 3. Analisa Fitokimia Ekstrak Kerik Daun Kluwih Pada Posisi Daun yang Berbeda

\begin{tabular}{ccccccc}
\hline \multirow{2}{*}{ Posisi Daun } & \multicolumn{7}{c}{ Komponen Kimia } \\
\cline { 2 - 7 } & Alkaloid & Triterpenoid & Flavonoid & Saponin & Fenolik & Tanin \\
\hline Muda & + & + & + & + & + & + \\
Tua & + & + & + & + & + & + \\
Sangat Tua & + & + & + & + & + & + \\
\hline
\end{tabular}

Adanya hasil positif terhadap alkaloid ditunjukan dengan terbentuknya warna jingga ketika sampel direaksikan dengan $\mathrm{HCl} 1 \%$ dan reagen dragendorf (Vogel, 1990). Alkaloid merupakan senyawa mengandung paling sedikit satu atom nitrogen yang bersifat basa dan pada umumnya merupakan bagian dari cincin heterosiklik (Kristanti, 2008).

Terbentuk warna unggu-merah ketika ekstrak kering daun kluwih yang telah ditambah $\mathrm{CHCl}_{3}$ dan asam asetat anhidratdireaksikan dengan $\mathrm{H}_{2} \mathrm{SO}_{4}$ pekat, menunjukan ekstrak positif mengandung triterpenoid. Terpenoid adalah kelompok senyawa metabolit sekunder yang terbesar, dilihat dari jumlah senyawa maupun variasi kerangka dasar strukturnya.Terpenoid banyak ditemukan dalam tanaman tingkat tinggi, meskipun demikian, dari penelitian diketahui bahwa jamur, organisme laut dan serangga juga menghasilkan terpenoid. Selain dalam bentuk bebasnya, terpenoid di alam juga ditemui dalam bentuk glikosida, glikosil ester, dan iridoid. Terpenoid juga merupakan komponen utama penyusun minyak atsiri (Kristanti, 2008).

Senyawa flavonoid yang diuji menggunakan logam magnesium dan asam klorida pekat menghasilkan warna merah tua Flavonoid adalah family besar yang disintesis oleh tanaman dengan struktur kimia dasar. Flavonoid umumnya merupakan komponen yang larut dalam air. Flavonoid pada tanaman berikatan dengan gula sebagai glikosida dan adapula yang berada dalam bentuk aglikon (Harborne, 1987). Flavonoid sangat efektif digunakan sebagai antioksidan, antibakteri dan inhibitor enzim $\alpha$-glukosidase (Bernardi, 2007; Sukadana, 2009; dan Hartika, 2009).

Hasil positif terhadap saponin ditunjukkan dengan timbulnya busa yang tidak hilang ketika ditambahkan $\mathrm{HCl} 2 \mathrm{~N}$. Saponin merupakan senyawa dalam bentuk glikosida yang tersebar luas pada tumbuhan tingkat tinggi. Saponin membentuk larutan koloidal dalam air dan membentuk busa apabila dilakukan pengocokkan dan tidak hilang dengan penambahan asam (Harbrone, 1987). Beberapa saponin bekerja sebagai antimikroba. Dikenal juga jenis saponin yaitu glikosida triterpenoid dan glikosida struktur steroid tertentu yang mempunyai rantai spirotekal. Kedua saponin ini larut dalam air dan etanol, tetapi tidak larut dalam eter. Aglikonnya disebut sapogenin, diperoleh dengan hidrolis dalam suasana asam atau hidrolisis memakai enzim (Robinson, 1995). Beragam senyawa struktur saponin juga telah diamati untuk membunuh protozoa, moluska, sebagai antioksidan, membantu penyerapan vitamin dan mineral dalam usus, menyebabkan hipoglikemia dan bertindak sebagai anti jamur dan anti virus (Yoshiki, 1998).

Berdasarkan hasil pengamatan diketahui bahwa semua ektrak kering daun kluwihmengandung senyawa fenolik, hal ini ditunjukan oleh adanya pembentukan senyawa kompleks antara besi dengan fenol yang memberikan warna hijau (Harborne, 19987). Disamping itu berdasarkan hasil pengamatan diketahui bahwa pada semua ekstrak kering daun kluwih juga terkandung adanya tanin. Hasil ini dapat ditunjukan dengani terbentuknya warna hijau kebiruan setelah penambahan besi (III) klorida $1 \%$ (Robinson, 1995).Tanin merupakan senyawa metabolit sekunder yang terdapat pada beberapa tanaman, yang tergolong dalam senyawa polifenol (Deaville, Givens, dan Harvey, 2010).Tanin alami larut dalam air dan memberikan warna pada air, warna larutan tanin bervariasi dari warna terang sampai warna merah gelap atau coklat, karena setiap tanin memiliki warna yang khas tergantung sumbernya (Ahadi, 2003). 


\section{Analisa Total Polifenol}

Analisis total polifenol dapat dilihat pada Gambar 4 berikut ini. Sebelumnya dilakukan pembuatan kurva standar asam galat deret konsentrasi 250 ppm, 500 ppm dan 1000 ppm (Gambar 3), di dapatkan persamaan garis linear $\mathrm{y}=0,0012 \mathrm{x}+0,015$.

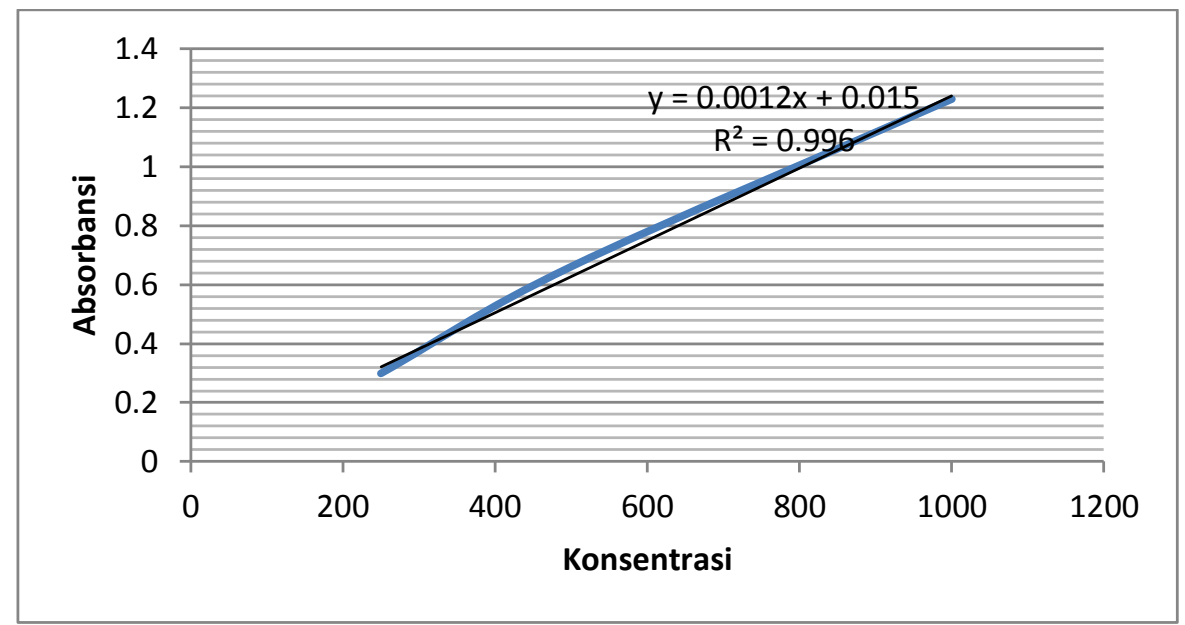

Gambar 3. Kurva Standar Asam Galat

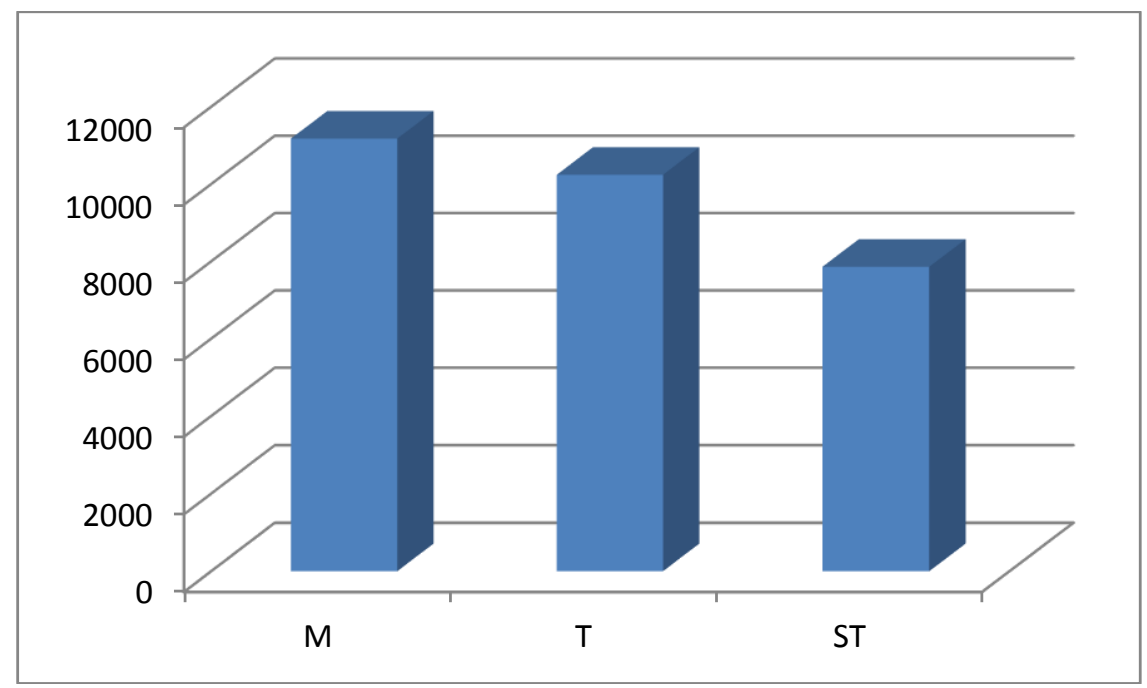

Gambar 4. Total Polifenol Ekstrak Kerik Daun Kluwih Pada Posisi Daun yang Berbeda

Dari Gambar 4 terlihat bahwa semua daun kluwih pada posisi berbeda mengandung total polifenol. Polifenol tertinggi terdapat pada daun muda kluwih. Total polifenol yang terkandung dapat berperan sebagai antioksidan. Total polifenol ekstrak daun kluwih berturut-turut berdasarkan posisi daun (muda, tua, dan sangat tua) adalah $11.175 \mathrm{mg} \mathrm{GAE} / \mathrm{g}, 10.238,89 \mathrm{mg} \mathrm{GAE} / \mathrm{g}$, dan 7.858,33 mg GAE/g. Nilai ini lebih tinggi jika dibandingkan dengan ekstrak air bawang dayak (139,39 mg GAE/g) (Febrinda, et al. 2013).

\section{KESIMPULAN}

Berdasarkan hasil penelitian diperoleh karakteristik dan komponen bioaktif ekstrak kering daun muda, tua dan sangat tua berturut-turut sebagai berikut: rendemen sebesar 5,49\%, 5,23\% dan 5,34\%; kadar air sebesar 10,11\%, 10,16\%, dan 10,30\%; kadar abu 12,76\%, 12,35\%, dan 12,30\%. Pada semua ekstrak daun mengandung alkaloid, triterpenoid, flavonoid, saponin, fenolik dan tanin. Total polifenol ekstrak kering daun muda, tua dan sangat tua berturut-turut, yaitu $11.175 \mathrm{mgGAE} / \mathrm{g}, 10.238,89$ $\mathrm{mgGAE} / \mathrm{g}$, dan 7.858,33 $\mathrm{mgGAE} / \mathrm{g}$. 


\section{DAFTAR PUSTAKA}

Ahadi MR. 2003. Kandungan Tanin Terkondensasi dan Laju Dekomposisi pada Serasah Daun (Rhizophora mucronata Lamk) pada Ekosistem Tambak Tumpang Sari di Belanakan, Purwakarta, Jawa Barat. [Skripsi]. Institut Pertanian Bogor.Bogor.

Bernardi APM, Lopez AC, Aspee A, Rech S, Poser GLV, Bride R, dan Lissp E. 2007. Antioxidant Activity of Flavonoids Isolated from Hyperincumternum. Journal Chil Chemistry Society. 52 ( 4): 1326-1329.

Deaville ER, Givens DI, dan Harvey MI. 2010. Chesnut and Mimosa Tannin Silages: Effect in Sheep Differ for Apparent Digestibilty, Nitrogen Utilitation and Losses. Animal Feed Science Technology.157: 129-138.

Febrinda AE, Astawan M, Wrediyanti T, Yuiana ND. 2013. Kapasitas Antioksidan dan Inhibitor Alfa Glukosidase Ekstrak Umbi Bawang Dayak. Journal Teknologi dan Imdustri Pangan. 24 (2): 161-167.

Harborne JB. 1987.Metode Fitokimia, Penuntun Cara Modern Menganalisa Tumbuhan.Terjemahan Kosasih Padmawinata dan Iwang Soediro. Terbitan Kedua. Penerbit ITB. Bandung.

Hartika R. 2009. Aktivitas Inhibisi A-Glukosidase Ekstrak Senyawa Golongan Flavonoid Buah Mahkota Dewa. [Skripsi]. Fakultas Matematika Dan Ilmu Pengetahuan Alam, Institut Pertanian Bogor. Bogor.

Khotimah K. 2014. Karakteristik kimia kopi kawa dari berbagai umur helai daun kopi yang diproses dengan metode berbeda. Jurnal Teknologi Pertanian 9 (1) : 40-48.

Kristianti AN,Aminah NS, Tanjung M, dan Kurniadi B. 2008. Buku Ajar Fitokimia.Airlangga University Press. Surabaya.

Mariane, Yuandani, Rosnani. 2011. Antidiabetic activity from ethanol extratc of kluwih's leaf (Artocarpus camansi). Jurnal Natural 11 (2): 64-68.

Nasution R, Barus T, Nasution P, Saidi N. 2014. Isolation and Elucidation of Steroid from Leaves of Artocapus camansi (Kulu) as Antidiabetic. International Journal of PharmTech Research 6 (4): 1279-1285.

Ragone D. 2006. Artocarpus camansi (beradnut). ver. 2.1. In: Elevitch CR (ed.).Species Profiles for Pacific IslandAgroforestry. Permanent Agriculture Resources (PAR), Holualoa, Hawai'i.

Robinson T. 1995. Kandungan Organik Tumbuhan Tinnggi.ITB. Bandung.

Shukor NA, Camp JV, Gonzales GB, Staljanssens D, Struijs K, Zotti MJ. Angiotensin-Converting Enzyme Inhibitory Effect By Plant Phenolic Compounds: a study of structure activity relentionships. J Agric Food Chem. 9:50-8.

Sukadana, M. 2009. "Aktivitas Antibakteri Senyawa Flavonoid dari Kulit Akar Awar-awar (Ficus septica Burn F)”. [Skripsi]. Universitas Udayana. Bali.

Supriyanto, Darmaji P, Baidiyah A. 2014. Pengaruh lama proses oksidasi enzimatis dan umur daun terhadap sifat kimia dan sensori teh daun tanaman kakao (Theobroma cacao, L.). Prosiding Seminar Nasional Sinergi PanganPakan dan Energi Terbarukan. 49-53.

Vogel AI. 1990. Buku Teks Analisis Anorganik Kualitatif Makro dan Semimikro. Kalman Media Pusaka. Jakarta.

Widyawati PS, Wijaya CH, Hardjosworo PS, Sajuthi D. 2011. Evaluasi aktivitas antioksidatif ekstrak daun beluntas (Plucea indica) berdasarkan perbedaan ruas daun. Rekapangan Jurnal Teknologi Pangan. 5 (1): 1-17.

Yenrina R. 2015. Metode Analisis Bahan Pangan dan Komponen Bioaktif. Andalas University Press. Padang

Yoshiki, Y, Kudo, dan Okobo, K. 1998. "Realtionship Between Cemical Structure and Biological Activities of Triterponoid Saponin from Soybean (Review)". Biosience Biotechnology and Biochemistry.62:2291-2292. 